\title{
Electrocatalytic Production of Hydrogen Gas by a Cobalt Formamidinate Complex
}

\author{
Yanyu $\mathrm{Wu}^{1}$, Luis M. Aguirre Quintana ${ }^{1}$, Karen Ventura ${ }^{1}$, Isabel Barraza Alvarez ${ }^{1}$, Alejandro Metta-
} Magaña ${ }^{1}$ and Dino Villagrán ${ }^{1, *}$

${ }^{1}$ Department of Chemistry and Biochemistry, The University of Texas at El Paso, El Paso, Texas 79968

Received September $4^{\text {th }}, 2018$; Accepted June 11 ${ }^{\text {th }}, 2019$.

DOI: http://dx.doi.org/10.29356/jmcs.v63i3.535

\begin{abstract}
A molecular cobalt complex, $\mathrm{Co}(\mathrm{DippF})_{2}$ (where DippF is the anion of N,N'-bis[2,6diisopropylphenyl]-formamidine), (1), is able to electrochemically produce hydrogen gas from the reduction of organic acids in homogeneous solutions. Compound $\mathbf{1}$ has a distorted square planar structure as evidenced through X-ray crystallography studies, and an effective magnetic moment of 4.13, obtained by the Evans method, that corresponds to three unpaired electrons. Compound 1 shows an irreversible cathodic peak at -1.59 $\mathrm{V} \mathrm{vs} \mathrm{Fc} / \mathrm{Fc}^{+}$which is assigned to the reduction of $\mathrm{Co}^{\mathrm{II}}$ to $\mathrm{Co}^{\mathrm{I}}$. In the presence of organic acids the onset of catalytic current is observed at $-1.2 \mathrm{~V},-1.45 \mathrm{~V}$ and $-1.89 \mathrm{~V}$ vs. $\mathrm{Fc} / \mathrm{Fc}^{+}$with $p$-toluenesulfonic acid, benzoic acid and phenol as the proton source, respectively, in $\mathrm{MeCN}$ as the solvent. Detection of hydrogen gas was obtained by GC-MS with Faradaic efficiencies ranging from $85 \%$ to $100 \%$. Kinetic studies using foot-of-thewave analysis (FOWA) reveal a linear dependence of the observed rate constant, $k_{\mathrm{obs}}$, against acid concentration in the range of 0.065 to $10.02 \mathrm{~s}^{-1}$.
\end{abstract}

Keywords: cobalt; formamidinate; electrocatalytic; hydrogen gas.

Resumen. Un complejo molecular de cobalto, Co(DippF)2 (donde DippF es el anión de la N,N'-bis[2,6diisopropilfenil]-formamidina), (1), es capaz de producir gas hidrógeno electroquímicamente mediante la reducción de ácidos orgánicos en soluciones homogéneas. El compuesto 1 tiene una estructura cuadrada plana distorsionada como se evidencia por estudios de cristalografía de rayos- $\mathrm{X}$, $\mathrm{y}$ un momento magnético efectivo de 4.13, obtenido por el método de Evans, que corresponde a tres electrones no apareados. El compuesto 1 muestra un pico catódico irreversible a $-1.59 \mathrm{~V}$ contra $\mathrm{Fc} / \mathrm{Fc}+$ que es asignado a la reducción de $\mathrm{CoII}$ a $\mathrm{CoI}$. En la presencia de ácidos orgánicos el principio de corriente catalítica se observa a $-1.2 \mathrm{~V},-1.45 \mathrm{~V} \mathrm{y}-1.89 \mathrm{~V}$ vs. $\mathrm{Fc} / \mathrm{Fc}+$ con ácido p-toluensulfónico, ácido benzoico y fenol como la fuente de protones, respectivamente, en $\mathrm{MeCN}$ como el solvente. La detección de gas hidrógeno fue obtenida por GC-MS con efíciencias faradaicas de $85 \%$ a $100 \%$. Estudios cinéticos usando análisis de base de onda (FOWA por sus siglas en inglés) revelan una dependencia lineal de la constante de reacción observada, kobs, contra la concentración de ácido en el rango de 0.065 a $10.02 \mathrm{~s}-1$.

Palabras clave: cobalto; formamidinato; electrocatalítico; gas hidrógeno.

\section{Introduction}

The exponential global economic and population growth has resulted in a rapid depletion of fossil fuel resources and in an increase of environmental concerns that accompany the combustion of these energy supplies.[1] Therefore exploring renewable, sustainable and clean alternative energy sources is fundamental to address these pressing issues.[1] Hydrogen gas produced through hydrogen evolution reactions (HERs) has been considered as a promising alternative fuel due to its high energy density, and its clean and carbon-free 
nature.[2-4] However, the main challenges of HERs are their high overpotential and sluggish kinetics.[5,6] Thus, to facilitate these reactions, efficient and robust catalysts are required.[7] Although platinum metal has been well demonstrated as the best HER electrocatalyst showing zero overpotential and large current density, its use is highly restricted by its high cost and scarcity.[8] In order to achieve more economically and environmentally viable hydrogen production, significant efforts have been made to explore earth-abundant materials based catalytic systems. $[9,10]$

Current research on HERs mainly focus on transition metal ( $\mathrm{Fe}, \mathrm{Co}, \mathrm{Ni}, \mathrm{Mn})$ and metal-free based electrocatalysts.[9,11-17] Molecular HER electrocatalysts have received substantial interest due to their ease of rational tuning of chemical properties and redox potentials to control their catalytic performance and selectivity.[18-20] In contrast to their bulk heterogeneous counterparts, homogeneous HER molecular catalysts allow for detailed mechanistic study of hydrogen generation by utilizing spectroscopic measurements, among other techniques.[21,22] One of the most frequently studied groups of molecular electrocatalysts are cobaltnitrogen coordinated complexes such as cobalt diglyoximes, cobalt porphyrins, cobalt salens, cobalt corroles and cobalt chlorins, etc.[23-29] Most of the cobalt complexes studied for hydrogen evolution are supported by electron-withdrawing ligands that tune the redox profile of the metal center by bringing the reduction potential to more anodic ranges, or by redox non-innocent ligands that can participate as electron reservoirs.[30-31] By contrast, cobalt-nitrogen coordinated complexes based HER electrocatalysts with electron-donating ligands are rare. Yet, the use of electron-donating ligands can potentially increase the electron-richness of the cobalt centers and, thus, enhance the reactivity at the catalytic center. Thus, further exploration of cobalt-nitrogen coordinated complexes bearing electron-donating ligands can provide new insight into the development of new ligand architectures that can improve the performance of homogeneous HER electrocatalysts.

Herein, we report the synthesis of a novel cobalt complex (1) where a single metal center is supported by two electron rich nitrogen-based DippF ligands (DippF = N,N'-bis[2,6-diisopropylphenyl]-formamidinate). We characterized 1 by spectroscopic means including UV-vis, nuclear magnetic resonance (NMR) spectroscopies and X-ray crystallography. Complex $\mathbf{1}$ was assessed as an electrocatalyst for hydrogen gas evolution by electrochemical measurements in $\mathrm{MeCN}$ with three different organic acids, namely $p$ toluenesulfonic (tosic) acid, benzoic acid and phenol. HER kinetic studies were also performed by foot-of-thewave analysis (FOWA) in order to provide insights of the relationship between rate constant and acid concentration.

\section{Experimental}

\section{General considerations}

Synthesis of $\mathbf{1}$ was accomplished using standard Schlenk techniques under $\mathrm{N}_{2}$ atmosphere and a dry $\mathrm{N}_{2}$-filled glovebox. All solvents used were dried using a Pure Process Technology solvent purification system.

\section{Materials}

All materials used were purchased from commercially available sources. Tetrabutylammonium hexafluorophosphate $\left(\mathrm{TBAPF}_{6}\right.$ ), $p$-toluenesulfonic (tosic) acid, benzoic acid, phenol and $\mathrm{CoCl}_{2} \cdot 6 \mathrm{H}_{2} \mathrm{O}$ were dried under vacuum at $60{ }^{\circ} \mathrm{C}$ prior to use. The remaining chemicals were used as received. HDippF was synthesized according to a previously reported method.[32]

\section{Physical measurements}

${ }^{1} \mathrm{H}$ NMR spectroscopy was recorded on a Bruker $400 \mathrm{MHz}$ NMR spectrometer, using deuterated benzene $\left(\mathrm{C}_{6} \mathrm{D}_{6}\right)$ as the solvent. The residual protic signal of $\mathrm{C}_{6} \mathrm{D}_{6}$ was used as the internal standard $(\delta=7.16$ ppm). UV-vis spectra were obtained using a SEC2000 instrument with a VISUAL SPECTRA 2.1 software.

\section{Information of X-ray crystal structure of 1}

A specimen of 1 was used for the X-ray crystallographic analysis. The X-ray intensity data were measured on a Bruker SMART APEX CCD system equipped with a graphite monochromator and a MoK $\alpha$ fine- 
focus tube $(\lambda=0.71073 \AA)$. The total exposure time was 4.00 hours. The frames were integrated with the Bruker SAINT software package using a narrow-frame algorithm. The integration of the data using an orthorhombic unit cell yielded a total of 22716 reflections to a maximum $\theta$ angle of $26.00^{\circ}(0.81 \AA$ resolution), of which 4567 were independent (average redundancy 4.974 , completeness $=100.0 \%$, Rint $=3.81 \%$, Rsig $=3.65 \%$ ) and 4362 $(95.51 \%)$ were greater than $2 \sigma(F 2)$. The final cell constants of $\mathrm{a}=14.4164(7) \AA, \mathrm{b}=20.1178(10) \AA, \mathrm{c}=$ $15.9876(8) \AA$, volume $=4636.8(4) \AA 3$, are based upon the refinement of the XYZ-centroids of 9910 reflections above $20 \sigma(\mathrm{I})$ with $4.784^{\circ}<2 \theta<57.66^{\circ}$. Data were corrected for absorption effects using the multi-scan method (SADABS). The ratio of minimum to maximum apparent transmission was 0.889 .

The structure was solved and refined using the Bruker SHELXTL Software Package, using the space group C 22 21, with $\mathrm{Z}=4$ for the formula unit, $\mathrm{C}_{50} \mathrm{H}_{68} \mathrm{CoN} 4$. The final anisotropic full-matrix least-squares refinement on F2 with 278 variables converged at $\mathrm{R} 1=5.46 \%$, for the observed data and $\mathrm{wR} 2=15.32 \%$ for all data. The goodness-of-fit was 1.088. The largest peak in the final difference electron density synthesis was $0.486 \mathrm{e}-/ \AA 3$ and the largest hole was $-0.612 \mathrm{e}-/ \AA 3$ with an RMS deviation of $0.079 \mathrm{e}-/ \AA 3$. On the basis of the final model, the calculated density was $1.123 \mathrm{~g} / \mathrm{cm} 3$ and $\mathrm{F}(000), 1692 \mathrm{e}-$.

Table 1. Data collection and structure refinement for $\mathbf{1}$.

\begin{tabular}{|l|c|}
\hline Diffractometer & Bruker SMART APEX CCD \\
\hline Radiation source & fine-focus tube, MoK $\alpha$ \\
\hline Theta range for data collection & 1.74 to $26.00^{\circ}$ \\
\hline Index ranges & $-17<=\mathrm{h}<=11,-24<=\mathrm{k}<=24,-19<=1<=19$ \\
\hline Reflections collected & 22716 \\
\hline Independent reflections & $4567[\mathrm{R}(\mathrm{int})=0.0381]$ \\
\hline $\begin{array}{l}\text { Coverage of independent } \\
\text { reflections }\end{array}$ & $100.0 \%$ \\
\hline Absorption correction & multi-scan \\
\hline Structure solution technique & direct methods \\
\hline Structure solution program & SHELXS-97(Sheldrick 2008) \\
\hline Refinement method & Full-matrix least-squares on $\mathrm{F}^{2}$ \\
\hline Refinement program & $\mathrm{SHELXL}-2014 / 6($ Sheldrick, 2014$)$ \\
\hline Function minimized & $\sum \mathrm{w}\left(\mathrm{F}_{\mathrm{o}}{ }^{2}-\mathrm{F}_{\mathrm{c}}{ }^{2}\right)^{2}$ \\
\hline Data / restraints / parameters & $4567 / 43 / 278$ \\
\hline Goodness-of-fit on $\mathbf{F}^{2}$ & 1.088 \\
\hline Final R indices & 4362 \\
\hline & data; $\mathrm{I}>2 \sigma(\mathrm{I})$ \\
\hline Weighting scheme & $\mathrm{all}$ \\
& data \\
\hline Absolute structure parameter & $\mathrm{w}=1 /\left[\sigma^{2}\left(\mathrm{~F}_{\mathrm{o}}{ }^{2}\right)+(0.0881 \mathrm{P})^{2}+7.7217 \mathrm{P}\right]$ \\
\hline Largest diff. peak and hole & where $\mathrm{P}=\left(\mathrm{F}_{\mathrm{o}}{ }^{2}+2 \mathrm{~F}_{\mathrm{c}}{ }^{2}\right) / 3$ \\
\hline R.M.S. deviation from mean & $0.0(0)$ \\
\hline & 0.486 and $-0.612 \mathrm{e} \AA^{-3}$ \\
\hline & $0.079 \mathrm{e} \AA^{-3}$ \\
\hline
\end{tabular}

\section{Evans method}

The magnetic susceptibility was measured through ${ }^{1} \mathrm{H}$ NMR spectroscopy, which was carried out with a sealed capillary tube containing pure $\mathrm{C}_{6} \mathrm{D}_{6}$ placed inside an NMR tube already loaded with a solution of $\mathbf{1}$ $(0.0160 \mathrm{~g})$ in $\mathrm{C}_{6} \mathrm{D}_{6}(1.5 \mathrm{~mL})$ in order to measure the chemical shift difference of the solvent caused by the different electronic environments. The number of unpaired electrons $(n)$ was calculated as shown below: $[33,34]$ 


$$
\chi_{\text {mass }}=\frac{3 \Delta f}{4 \pi f m}+\chi_{0}+\frac{\chi_{0}\left(d_{0}-d_{s}\right)}{m}
$$

where, $\chi_{\text {mass }}$ is the mass susceptibility, $\Delta f$ is the frequency separation, $f$ is the NMR frequency being studied $\left(400 * 10^{6} \mathrm{~Hz}\right), \mathrm{m}$ is the mass concentration $\left(\mathrm{g} / \mathrm{cm}^{3}\right)$ of $1, \chi_{0}$ is the mass susceptibility of the solvent $\left(-8.8^{*} 10^{-9}\right.$ $\mathrm{m}^{3} / \mathrm{kg}$ for benzene), $d_{\mathrm{o}}$ is the density of the solvent and $d_{\mathrm{s}}$ is the density of the solution.

The molar susceptibility $\left(\chi_{M}\right)$ is given by:

$$
\begin{aligned}
& \chi_{M}=\mathrm{M} \chi_{\text {mass }} \\
& \chi_{M}=N_{0} \mu_{0} \xi+\chi_{M}^{\text {para }} \\
& \chi_{M}^{\text {para }}=\chi_{M}-N_{0} \mu_{0} \xi
\end{aligned}
$$

where, $N_{0}$ is the Avogadro's number, $\mu_{0}$ is the vacuum permeability $\left(4 \pi^{*} 10^{-7} \mathrm{NA}^{-2}\right), \xi$ is magnetizability, $N_{0} \mu_{0} \xi$ is the diamagnetic contribution and $\chi_{M}^{\text {para }}$ is the paramagnetic contribution. The effective paramagnetic moment is expressed as:

$$
\mu_{\text {eff }}=797.8 \sqrt{T \chi_{M}^{\text {para }}} \text { Bohr Magneton }
$$

The number of unpaired electrons $(n)$ can be finally calculated through:

$$
\mu_{e f f}(\operatorname{spin} \text { only })=\sqrt{n(n+2)}
$$

\section{Synthesis of 1}

Synthesis of 1 was performed in a dried $\mathrm{N}_{2}$-filled glovebox. Anhydrous $\mathrm{CoCl}_{2}(0.500 \mathrm{~g}, 3.85 \mathrm{mmol})$ was dissolved in $20 \mathrm{~mL}$ THF using a $50 \mathrm{~mL}$ round-bottom flask. Then, HDippF ( $2.80 \mathrm{~g}, 7.70 \mathrm{mmol})$ was added to the solution. Subsequently, methyllithium $(4.81 \mathrm{~mL}, 7.70 \mathrm{mmol})$ was added using a glass syringe. The solution changed from a sky blue to a dark aqua-green color. The resulting solution was allowed to vigorously stir under room temperature for three hours. Afterwards, diethyl ether $\left(\mathrm{Et}_{2} \mathrm{O}\right)$ was added to precipitate the $\mathrm{LiCl}$ byproduct. The resulting suspension was filtered using a medium coarse glass frit packed with Celite. The filtrate was dried under reduced pressure to obtain $1.058 \mathrm{~g}$ of the final green product. The product was crystallized using of a concentrated solution of Et $2 \mathrm{O}$. Yield 35.05\%. UV-vis: $\lambda$ max: 564, 628, and $674 \mathrm{~nm}$. 


\section{Electrochemical measurements}

Electrochemical measurements were recorded on a CHI760D potentiostat using a three-electrode electrochemical cell in a dry $\mathrm{N}_{2}$-filled glovebox, with glassy carbon ( $4 \mathrm{~mm}$ diameter) as the working electrode, platinum wire and $\mathrm{Ag} / \mathrm{Ag}^{+}$as the counter and reference electrode, respectively. Ferrocene (Fc) was added subsequently after each measurement as an internal reference and all potentials displayed are referred to ferrocene/ferrocenium $\left(\mathrm{Fc} / \mathrm{Fc}^{+}\right)$redox couple.

\section{Hydrogen gas detection}

Hydrogen gas was confirmed and quantified using a Gas Chromatograph (GC) after performing bulk electrolysis. Bulk electrolysis was operated using a sealed custom-built three-electrode electrochemical cell with an $\mathrm{H}$ shape. The working electrode $\left(1 \mathrm{~cm}^{2}\right.$ carbon rod), reference electrode $\left(\mathrm{Ag} / \mathrm{Ag}^{+}\right)$were separated with the counter electrode (Pt mesh) through a glass frit. Solutions containing $50 \mathrm{~mL}$ of $1 \mathrm{mM}$ of $1,0.1 \mathrm{M}_{\text {of TBAPF }}$ and $10 \mathrm{mM}$ of the respective acid studied (tosic acid, benzoic acid, phenol) in MeCN were used for bulk electrolysis at a constant potential of $-2.0 \mathrm{~V}$ vs. $\mathrm{Fc} / \mathrm{Fc}^{+}$for an hour. An aliquot of $300 \mu \mathrm{L}$ of the gas in the headspace in the side of the cell containing the working electrode was injected to the GC for analysis.

\section{Calculation of $\boldsymbol{k}_{o b s}$ and $\boldsymbol{k}_{\text {cat }}$ from foot-of-the-wave analysis (FOWA)}

The HER kinetics can be measured by the foot-of-the-wave analysis (FOWA), which has been developed by Savéant and coworkers.[35] For an ECEC or ECCE mechanistic process,[35-36] the current is described by:

$$
i=\frac{2 \mathrm{FA} C_{p}^{0} \sqrt{\mathrm{D} k_{o b s}}}{1+e^{\left[\frac{F}{R T}\left(E-E_{c a t / 2}\right)\right]}}
$$

where, $\mathrm{F}$ is the Faraday constant $(96485 \mathrm{C} / \mathrm{mol}), \mathrm{A}$ is the surface area of the working electrode $\left(\mathrm{cm}^{2}\right), \mathrm{C}_{\mathrm{p}}^{0}$ is the concentration of the catalyst $(\mathrm{mol} / \mathrm{L}), \mathrm{D}$ is the diffusion coefficient $\left(\mathrm{cm}^{2} / \mathrm{s}\right)$ and $k_{o b s}$ is the observed rate constant.

According to the Randles-Sevcik equation, the peak current is:[37]

$$
i_{p}=0.4463 \mathrm{FAC}_{\mathrm{p}}^{0} \sqrt{\frac{\mathrm{F} v \mathrm{D}}{\mathrm{RT}}}
$$

where, $v$ is the scan rate.

By diving Eq.7 with Eq.8, we can get:

$$
\frac{i}{i_{p}}=\frac{2 \sqrt{\frac{\mathrm{RT}}{\mathrm{Fv}}} \sqrt{k_{o b s}}}{0.4463} * \frac{1}{1+e^{\left[\frac{\mathrm{F}}{\mathrm{RT}}\left(\mathrm{E}-\mathrm{E}_{\mathrm{cat} / 2}\right)\right]}}
$$




$$
\begin{aligned}
& \text { After plotting } \frac{i}{i_{p}} \text { versus } \frac{1}{1+e^{\left[\frac{\mathrm{F}}{\mathrm{RT}}\left(\mathrm{E}-\mathrm{E}_{\mathrm{cat} / 2}\right)\right]}} \text { from the linear region we can obtain a slope of } m \text {, which } \\
& m=\frac{2 \sqrt{\frac{\mathrm{RT}}{\mathrm{F} v}} \sqrt{k_{o b s}}}{0.4463}
\end{aligned}
$$

Thus $k_{o b s}$ can be obtained from

$k_{o b s}=\frac{(m)^{2}(0.4463)^{2} \mathrm{Fv}}{4 \mathrm{RT}}$

Then the catalytic rate constant $\left(k_{c a t}\right)$ is calculated from:

$$
k_{c a t}=\frac{k_{o b s}}{\left[\mathrm{H}^{+}\right]}
$$

\section{Calculation of structural geometry index $\tau_{4}$ for a mononuclear 4-coordinate complex}

To disambiguate whether 1 bears closer structural resemblance to a square planar or tetrahedral complex, the model proposed by Yang et al. (Eq. 13) was used. ${ }^{38}$ In this equation, where $\tau_{4}$ is the structural index, $\beta$ and $\alpha$ are the two largest valence angles in a 4-coordinate molecule respectively, and $\theta$ is $109.5^{\circ}$. For a 4-coordinate species, a $\tau_{4}$ of 1 represents a tetrahedral molecule while a $\tau_{4}$ of 0 indicates a square planar molecule.

$$
\tau_{4}=\frac{360-(\beta+\alpha)}{360-2 \theta}
$$




\section{Results and discussion}
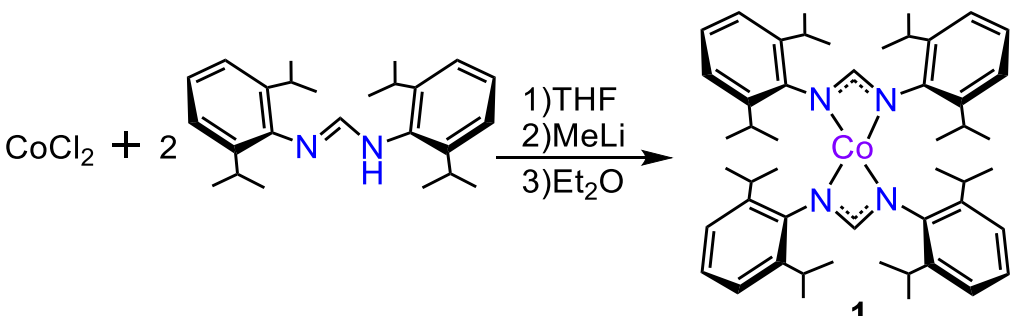

Scheme 1. Synthetic scheme of 1 .

The solid-state structure of 1 was confirmed by X-ray crystallography (Fig. 1) and the detailed crystallographic data are summarized in Table 2. The bond distances of $\mathrm{Co}(1)-\mathrm{N}(1)$ and $\mathrm{Co}(1)-\mathrm{N}(2)$ are 1.998(3) $\AA$ and 1.999(3) $\AA$, respectively, which are longer than those of the reported Co diglyoxime complex (1.886(5) A).[23] The N2-Co1-N2, N1-Co1-N1, N2-Co1-N1 bond angles are found to be $155.0^{\circ}(2), 151.0^{\circ}$ (2), and $119.66^{\circ}$ (14) respectively. Based on the bond angles, the calculated geometry index $\tau_{4}$ is 0.38 . Thus, 1 is assigned as a distorted square planar complex.

Table 2. Sample and crystal data for $\mathbf{1 .}$

\begin{tabular}{|l|l|l|}
\hline Identification code & \multicolumn{2}{|l|}{$\mathrm{Co}(\mathrm{DippF})_{2}$} \\
\hline Chemical formula & $\mathrm{C}_{50} \mathrm{H}_{68} \mathrm{CoN}_{4}$ & \multicolumn{1}{l|}{} \\
\hline Formula weight & $784.01 \mathrm{~g} / \mathrm{mol}$ & \\
\hline Temperature & $100(2) \mathrm{K}$ \\
\hline Wavelength & $0.71073 \AA$ & $\alpha=90^{\circ}$ \\
\hline Crystal system & orthorhombic & \\
\hline Space group & $\mathrm{C} 2221$ & $\gamma=90^{\circ}$ \\
\hline Unit cell dimensions & $\mathrm{a}=14.4164(7) \AA$ & $\gamma=90^{\circ}$ \\
\hline & $\mathrm{b}=20.1178(10) \AA$ & \\
\hline & $\mathrm{c}=15.9876(8) \AA$ & \\
\hline Volume & $4636.8(4) \AA^{3}$ & \\
\hline Z & 4 & \\
\hline Density (calculated) & $1.123 \mathrm{~g} / \mathrm{cm}^{3}$ & \\
\hline Absorption coefficient & $0.406 \mathrm{~mm}^{-1}$ & \\
\hline F(000) & 1692 \\
\hline
\end{tabular}




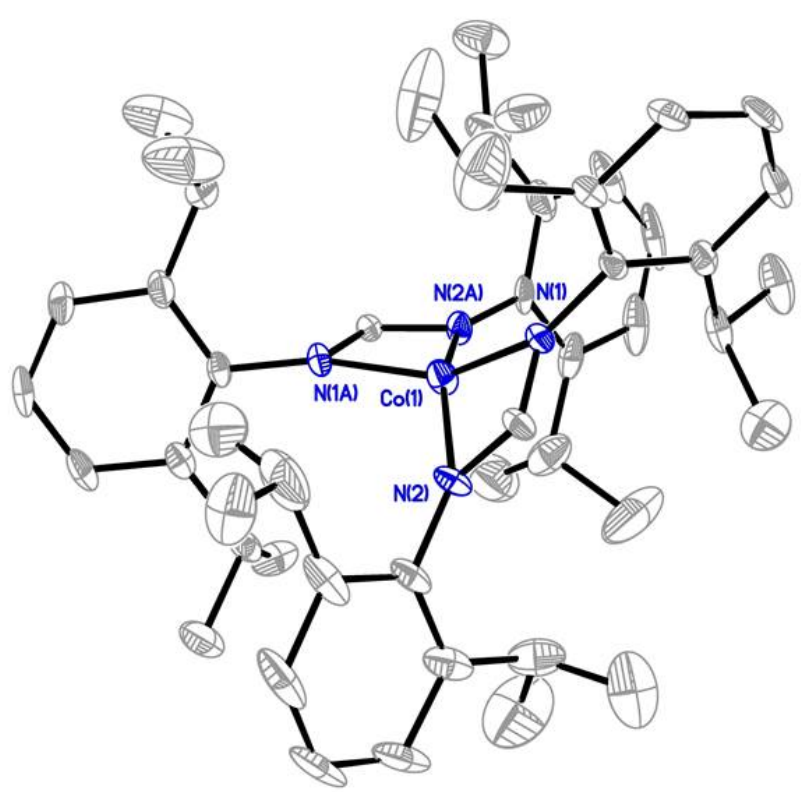

Fig. 1. Solid-state crystal structure of 1 with thermal ellipsoid shown to be $50 \%$. Hydrogen atoms were omitted for clarity. $\mathrm{R}(\mathrm{int})=8.58 \%, \mathrm{R}($ sigma $)=2.95 \%$.

Characterization of 1 by ${ }^{1} \mathrm{H}$ NMR proved challenging due to the intense paramagnetic broadening of the observed signals, reflecting the paramagnetic nature of the complex, and consistent with previous reports of 4-coordinate $\mathrm{d}^{7} \mathrm{Co}(\mathrm{II})$ complexes.[39,40] The magnetic susceptibility of $\mathbf{1}$ was probed through the Evans method. The ${ }^{1} \mathrm{H}$ NMR signal for benzene is shifted by $+0.51 \mathrm{ppm}$ in the presence of 1 , resulting in a $\mu_{\text {eff }}$ of 4.13 corresponding to three unpaired electrons (vide supra). This is consistent with other 4-coordinate cobalt complexes bearing nitrogen-donor ligands.[41] The higher $\mu_{\text {eff }}$ value compared to the predicted spin-only $\mu_{\text {eff }}$ of 3.87 is attributed to the typical spin-orbit coupling experienced by cobalt.[42,43]

Cyclic voltammograms (CVs) of 1 are presented in Figures 2-4. Compound 1 shows one nonreversible one-electron reduction wave at $\mathrm{E}_{\mathrm{p}}=-1.59 \mathrm{~V}$ vs. $\mathrm{Fc} / \mathrm{Fc}^{+}$, resulting from the $\mathrm{Co}{ }^{\mathrm{II}} / \mathrm{Co}^{\mathrm{I}}$ reduction couple. The nonreversibility of this event can be attributed to the electron-rich nature of 1 . Upon addition of tosic acid $\left(p K_{\mathrm{a}}=\right.$ 8.5 in $\mathrm{MeCN}$ ), a catalytic wave is observed with an onset potential of $-1.2 \mathrm{~V} \mathrm{vs.} \mathrm{Fc} / \mathrm{Fc}^{+}$, accompanying with another reduction wave at $\mathrm{E}_{\mathrm{p}}=-1.73 \mathrm{~V} \mathrm{vs}$. $\mathrm{Fc} / \mathrm{Fc}^{+}$. Another two significantly less acidic proton sources, namely benzoic acid $\left(p \mathrm{~K}_{\mathrm{a}}=21.51\right.$ in $\left.\mathrm{MeCN}\right)$ and phenol $\left(p \mathrm{~K}_{\mathrm{a}}=29.14\right.$ in $\left.\mathrm{MeCN}\right)$, were also introduced to evaluate the electrocatalytic activity of $\mathbf{1}$. The CVs of $\mathbf{1}$ upon addition of both benzoic acid and phenol show considerable increase of cathodic catalytic current for proton reduction, with an onset potential of $-1.45 \mathrm{~V}$ and $-1.89 \mathrm{~V}$ vs. $\mathrm{Fc} / \mathrm{Fc}^{+}$for benzoic acid and phenol, respectively (Figures 3-4). The ability of $\mathbf{1}$ to catalyze proton reduction in weak acidic media, which is noteworthy for this type of study, can be attributed to the enhanced electro-activity of the cobalt center due to the electron-donating formamidinate ligand. Hydrogen gas detection and quantification were carried out after performing bulk electrolysis for an hour at a constant potential of $-2.0 \mathrm{~V}$ vs. $\mathrm{Fc} / \mathrm{Fc}^{+}$using $1 \mathrm{mM}$ of 1 and $10 \mathrm{mM}$ of the chosen acids. The accumulated charge over time (Fig. 5) shows 36.16, 14.26, 8.08 $\mathrm{C}$ of the passed charge for an hour of electrolysis when using tosic acid, benzoic acid and phenol, respectively, corresponding to Faradaic efficiencies of $91.4 \%, 85.0 \%$ and $100 \%$ for hydrogen production. 




Fig. 2. Cyclic voltammograms of $1 \mathrm{mM} 1$ without acid (black line) and with tosic acid (colored lines) in $\mathrm{MeCN}$ solution containing $0.1 \mathrm{M} \mathrm{TBAPF}_{6}$. Scan rate: $100 \mathrm{mV} / \mathrm{s}$; glassy carbon electrode (4 mm diameter).



Fig. 3. Cyclic voltammograms of $1 \mathrm{mM} 1$ without acid (black line) and with benzoic acid (colored lines) in $\mathrm{MeCN}$ solution containing $0.1 \mathrm{M} \mathrm{TBAPF}_{6}$. Scan rate: $100 \mathrm{mV} / \mathrm{s}$; glassy carbon electrode (4 mm diameter). 


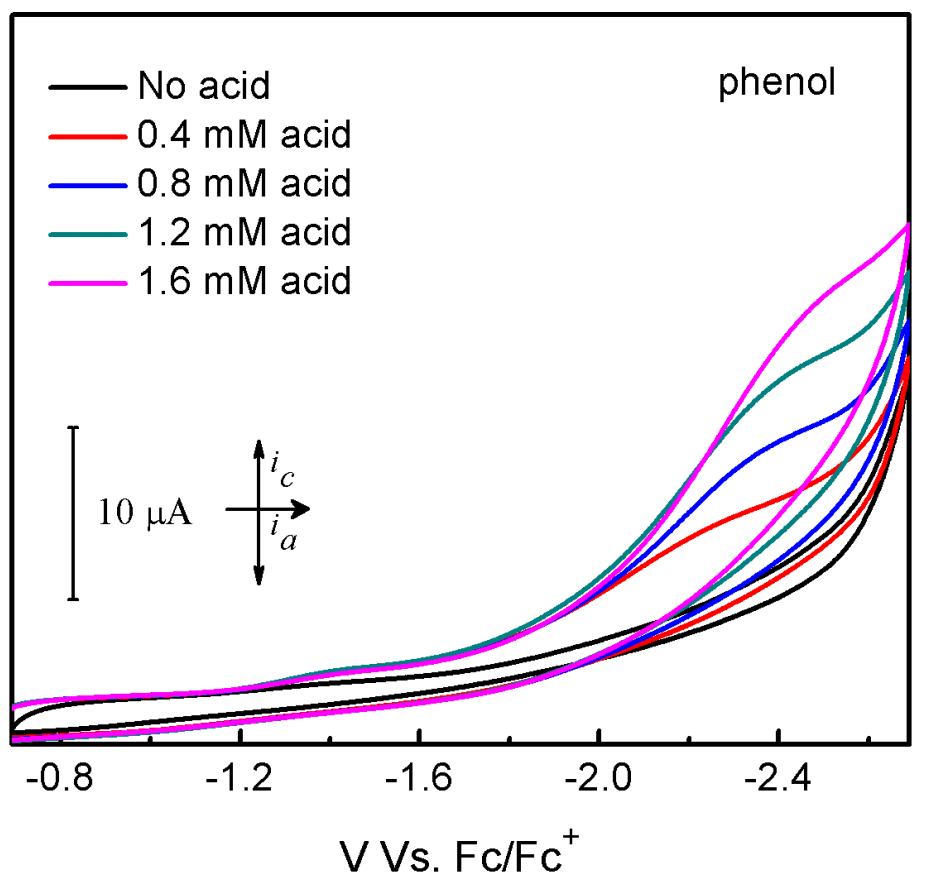

Fig. 4. Cyclic voltammograms of $1 \mathrm{mM} 1$ without acid (black line) and with phenol (colored lines) in $\mathrm{MeCN}$ solution containing $0.1 \mathrm{M} \mathrm{TBAPF}_{6}$. Scan rate: $100 \mathrm{mV} / \mathrm{s}$; glassy carbon electrode (4 mm diameter).

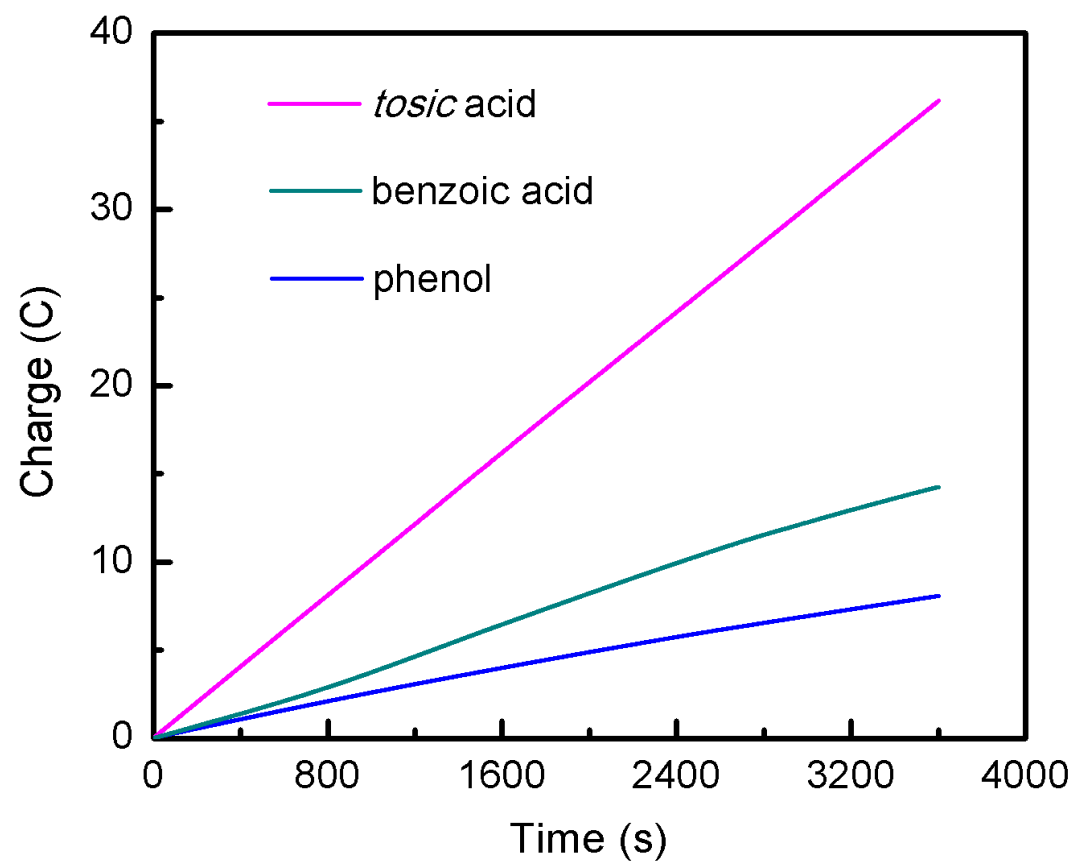

Fig. 5. Bulk electrolysis experiments of $1 \mathrm{mM} 1$ containing $10 \mathrm{mM}$ of tosic acid, benzoic acid and phenol, respectively. Applied potential: $-2.0 \mathrm{~V}$ vs. $\mathrm{Fc} / \mathrm{Fc}^{+}$. 
The reaction kinetics of HER using 1 with tosic acid was studied through the use of foot-of-the-wave analysis (FOWA). The FOWA plot is presented in Fig. 6 (a), which is derived from the linear sweep voltammograms shown in Fig. 6 (b). The observed rate constants $\left(k_{o b s}\right)$ and catalytic rate constants $\left(k_{\text {cat }}\right)$ at different concentrations of acid addition are summarized in Table 3 (see experimental section for detailed calculation). The relationship of $k_{o b s}$ with acid concentration is linear (Fig. 7), suggesting there is a first order dependence on acid concentration.
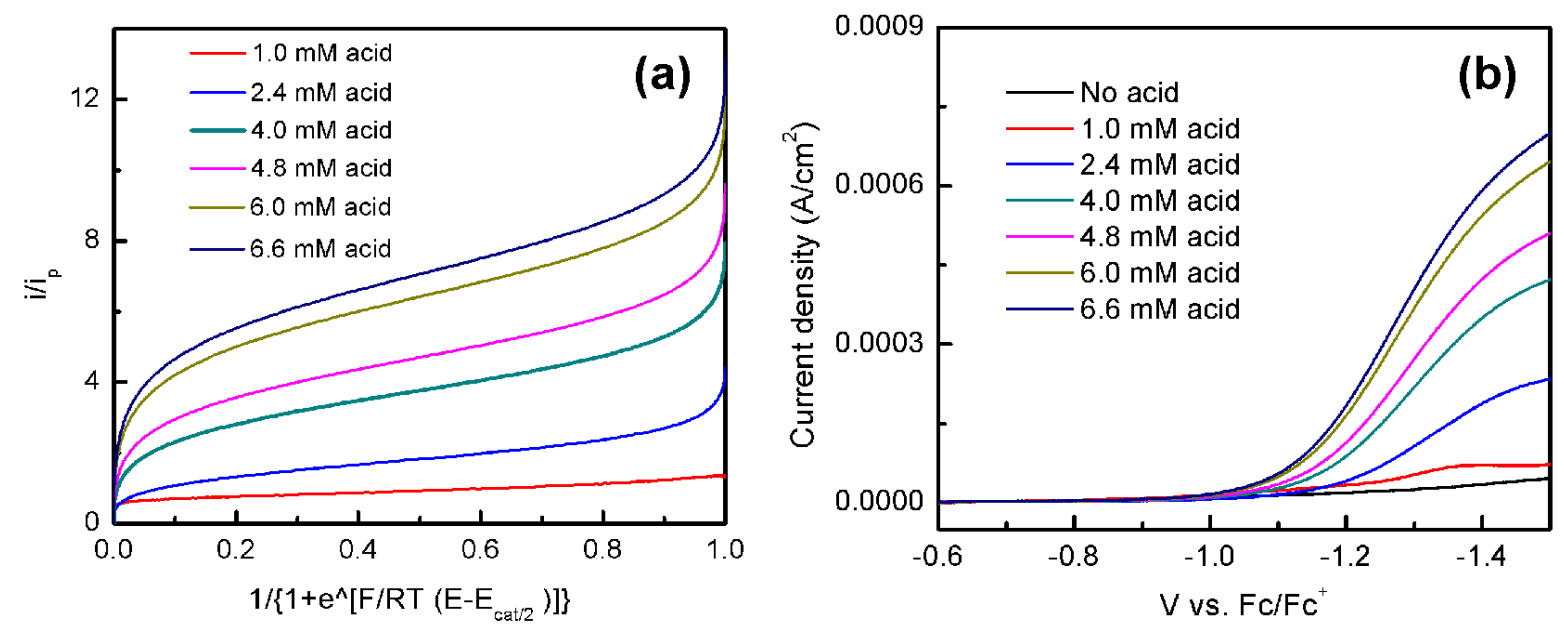

Fig. 6. (a) FOWA plots of $1 \mathrm{mM}$ of 1 at different concentration of tosic acid. Scan rate: $100 \mathrm{mV} / \mathrm{s}$; (b) Linear sweep voltammograms of $\mathbf{1}$ in $\mathrm{MeCN}$ with $0.1 \mathrm{M} \mathrm{TBAPF}_{6}$ titration with tosic acid.

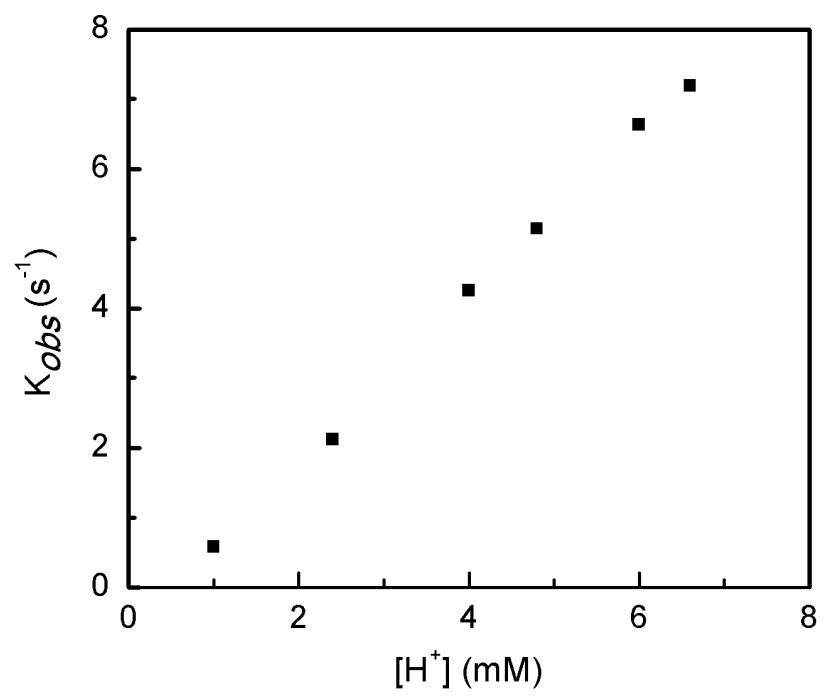

Fig. 7. Plots of observed rate constant $\left(k_{o b s}\right)$ versus acid concentration $\left(\left[\mathrm{H}^{+}\right]\right)$. 
Table 3. Summary of the results of FOWA slope $(m), k_{o b s}$ and $k_{c a t}$ at different acid concentration.

\begin{tabular}{|c|c|c|c|}
\hline$\left[\mathbf{H}^{+}\right](\mathbf{m M})$ & $\mathbf{M}$ & $\boldsymbol{k}_{\text {obs }}\left(\mathbf{s}^{\mathbf{- 1}}\right)$ & $\boldsymbol{k}_{\text {cat }}\left(\mathbf{M}^{-1} \mathbf{s}^{-1}\right)$ \\
\hline 1.0 & 0.58 & 0.0652 & 65.2 \\
\hline 2.4 & 2.12 & 0.872 & 363 \\
\hline 4.0 & 4.25 & 3.50 & 875 \\
\hline 4.8 & 5.14 & 5.12 & 1066 \\
\hline 6.0 & 6.63 & 8.52 & 1420 \\
\hline 6.6 & 7.19 & 10.02 & 1518 \\
\hline
\end{tabular}

\section{Conclusion}

In conclusion, we have successfully synthesized a cobalt complex anchored by formamidinate ligand. Structural analysis by X-ray crystallography shows that $\mathbf{1}$ has a distorted square planar chemical structure and magnetic susceptibility measurements show a $\mu_{\text {eff }}$ of 4.13 B.M. at room temperature, indicative of an electronic structure bearing three unpaired electrons. This molecule is found to be active for electrochemical hydrogen generation with both strong acid and weak acid substrates in $\mathrm{MeCN}$. The electrochemical onset potentials for hydrogen generation range from $-1.2 \mathrm{~V}$ to $-1.89 \mathrm{~V}$ vs. $\mathrm{Fc} / \mathrm{Fc}^{+}$. This work shows the potential of using electron rich ligand architectures for tuning the redox activity of cobalt HER electrocatalysts.

\section{Acknowledgment}

This work was financially supported by NSF under award number CHE-1305124. LMAQ thanks COURI-Meritus at UTEP and CCI-Solar for research finance. IBA thanks MARC for an undergraduate scholarship.

\section{References}

1. Gray, H. B. Nat. Chem. 2009, 1 (1), 7-7.

2. Cook, T. R.; Dogutan, D. K.; Reece, S. Y.; Surendranath, Y.; Teets, T. S.; Nocera, D. G. Chem. Rev. 2010, $110(11), 6474-6502$.

3. Lewis, N. S.; Nocera, D. G. Proc. Natl. Acad. Sci. 2006, 103 (43), 15729-15735.

4. Sanchez, J.; Ramos-Garcés, M. V.; Narkeviciute, I.; Colón, J. L.; Jaramillo, T. F. Catalysts 2017, 7 (5), 132.

5. Wang Lihuan; Tranca Diana C.; Zhang Jian; Qi Yanpeng; Sfaelou Stavroula; Zhang Tao; Dong Renhao; Zhuang Xiaodong; Zheng Zhikun; Seifert Gotthard. Small 2017, 13 (37), 1700783.

6. Turner, J. A. Science 2004, 305 (5686), 972-974.

7. Thoi, V. S.; Sun, Y.; Long, J. R.; Chang, C. J. Chem. Soc. Rev. 2013, 42 (6), 2388-2400. 
8. Popczun, E. J.; Read, C. G.; Roske, C. W.; Lewis, N. S.; Schaak, R. E. Angew. Chem. Int. Ed Engl. 2014, 53 (21), 5427-5430.

9. Wang, M.; Chen, L.; Sun, L. Energy Environ. Sci. 2012, 5 (5), 6763-6778.

10. Faber, M. S.; Lukowski, M. A.; Ding, Q.; Kaiser, N. S.; Jin, S. J. Phys. Chem. C 2014, 118 (37), 21347-21356.

11. 11. Chen, X.; Wang, D.; Wang, Z.; Zhou, P.; Wu, Z.; Jiang, F. Chem. Commun. 2014, 50 (79), $11683-11685$.

12. 12. Bediako, D. K.; Solis, B. H.; Dogutan, D. K.; Roubelakis, M. M.; Maher, A. G.; Lee, C. H.; Chambers, M. B.; Hammes-Schiffer, S.; Nocera, D. G. Proc. Natl. Acad. Sci. U. S. A. 2014, 111 (42), 15001-15006.

13. 13. Bayati, M. Chemcatchem 2017, 9.

14. 14. Patra, B. C.; Khilari, S.; Manna, R. N.; Mondal, S.; Pradhan, D.; Pradhan, A.; Bhaumik, A. ACS Catal. 2017, 7 (9), 6120-6127.

15. 15. Yap, C. P.; Poh, H. T.; Fan, W. Y. RSC Adv. 2016, 6 (7), 5903-5906.

16. 16. Zheng, Y.; Jiao, Y.; Zhu, Y.; Li, L. H.; Han, Y.; Chen, Y.; Du, A.; Jaroniec, M.; Qiao, S. Z. Nat. Commun. 2014, 5, ncomms4783.

17. 17. Wu, Y.; Zarei-Chaleshtori, M.; Torres, B.; Akter, T.; Diaz-Moreno, C.; Saupe, G. B.; Lopez, J. A.; Chianelli, R. R.; Villagrán, D. Int. J. Hydrog. Energy 2017, 42 (32), 20669-20676.

18. 18. Solis, B. H.; Hammes-Schiffer, S. J. Am. Chem. Soc. 2011, 133 (47), 19036-19039.

19. 19. Matson, B. D.; Peters, J. C. ACS Catal. 2018, 8 (2), 1448-1455.

20. 20. McCrory, C. C. L.; Uyeda, C.; Peters, J. C. J. Am. Chem. Soc. 2012, 134 (6), 3164-3170.

21. 21. Marinescu, S. C.; Winkler, J. R.; Gray, H. B.Proc. Natl. Acad. Sci. 2012, 109 (38), 15127-15131.

22. 22. Solis, B. H.; Maher, A. G.; Dogutan, D. K.; Nocera, D. G.; Hammes-Schiffer, S. Proc. Natl. Acad. Sci. 2016, 113 (3), 485-492.

23. 23. Hu, X.; Brunschwig, B. S.; Peters, J. C. J. Am. Chem. Soc. 2007, 129 (29), 8988-8998.

24. 24. Bhugun, I.; Lexa, D.; Savéant, J.-M.J. Am. Chem. Soc. 1996, 118 (16), 3982-3983.

25. 25. Lee, C. H.; Dogutan, D. K.; Nocera, D. G. J. Am. Chem. Soc. 2011, 133 (23), 8775-8777.

26. 26. Kaeffer, N.; Chavarot-Kerlidou, M.; Artero, V. Acc. Chem. Res. 2015, 48 (5), 1286-1295.

27. 27. Mondal, B.; Sengupta, K.; Rana, A.; Mahammed, A.; Botoshansky, M.; Dey, S. G.; Gross, Z.; Dey, Inorg. Chem. 2013, 52 (6), 3381-3387.

28. 28. Beyene, B. B.; Mane, S. B.; Hung, C.-H. Chem. Commun. 2015, 51 (81), 15067-15070.

29. 29. Fihri, A.; Artero, V.; Razavet, M.; Baffert, C.; Leibl, W.; Fontecave, M. Angew. Chem. Int. Ed Engl. 2008, 47 (3), 564-567.

30. 30. Jurss, J. W.; Khnayzer, R. S.; Panetier, J. A.; Roz, K. A. E.; Nichols, E. M.; Head-Gordon, M.; Long, J. R.; Castellano, F. N.; Chang, C. J. Chem. Sci. 2015, 6 (8), 4954-4972.

31. 31. Chen, L.; Khadivi, A.; Singh, M.; Jurss, J. W. Inorg. Chem. Front. 2017, 4 (10), 1649-1653.

32. 32. Elkin, T.; Kulkarni, N. V.; Tumanskii, B.; Botoshansky, M.; Shimon, L. J. W.; Eisen, M. S. Organometallics 2013, 32 (21), 6337-6352.

33. 33. Evans, D. F. 400.J. Chem. Soc. Resumed 1959, 0 (0), 2003-2005.

34. 34. Ostfeld, D.; Cohen, I. A. J. Chem. Educ. 1972, 49 (12), 829.

35. 35. Costentin, C.; Drouet, S.; Robert, M.; Savéant, J.-M. J. Am. Chem. Soc. 2012, 134 (27), 1123511242 .

36. 36. Rountree, E. S.; McCarthy, B. D.; Eisenhart, T. T.; Dempsey, J. L. Inorg. Chem. 2014, 53 (19), 9983-10002.

37. 37. Rountree, E. S.; Martin, D. J.; McCarthy, B. D.; Dempsey, J. L. ACS Catal. 2016, 6 (5), 33263335 . 
38. 38. Yang, L.; Powell, D. R.; Houser, R. P. Dalton Trans. Camb. Engl. 2003 2007, No. 9, 955-964.

39. 39. Maher, A. G.; Passard, G.; Dogutan, D. K.; Halbach, R. L.; Anderson, B. L.; Gagliardi, C. J.; Taniguchi, M.; Lindsey, J. S.; Nocera, D. G. ACS Catal. 2017, 7 (5), 3597-3606.

40. 40. Fryzuk, M. D.; Leznoff, D. B.; Thompson, R. C.; Rettig, S. J. J. Am. Chem. Soc. 1998, 120 (39), 10126-10135.

41. 41. Carabineiro, S. A.; Silva, L. C.; Gomes, P. T.; Pereira, L. C. J.; Veiros, L. F.; Pascu, S. I.; Duarte, M. T.; Namorado, S.; Henriques, R. T. Inorg. Chem. 2007, 46 (17), 6880-6890.

42. 42. Fink, K.; Wang, C.; Staemmler, V. Inorg. Chem. 1999, 38 (17), 3847-3856.

43. 43. Gerloch, M.; Quested, P. N. J. Chem. Soc. Inorg. Phys. Theor. 1971, 0 (0), 3729-3741. 